\title{
IPTEKS PENGENDALIAN INTERN SIMDA KEUANGAN DALAM PENGELOLAAN DATA KEUANGAN PADA BADAN PERENCANAAN DAN PEMBANGUNAN DAERAH (BAPPEDA) PROVINSI SULAWESI UTARA
}

\author{
Imanuel Ronaldo Angelo Polii ${ }^{1}$, Winston Pontoh $^{2}$ \\ 1,2Jurusan Akuntansi, Fakultas Ekonomi dan Bisnis Universitas Sam Ratulangi, Jl. Kampus Unsrat, Manado, \\ 95115, Indonesia
}

Email: angeloirpolii@gmail.com

\begin{abstract}
As a government agency, Local Development Planning Agency (BAPPEDA) of North Sulawesi Province is a Local Government Work Unit (SKPD) that has the task of helping the Governor in terms of planning and execution of regional policies. In order to create good regional financial management, BAPPEDA of North Sulawesi Province implements Financial SIMDA in its financial data management system. Financial SIMDA is an application developed by BPKP to facilitate local government in implementing good regional financial management. The use of Financial SIMDA produces output in the planning, administration, accounting and reporting processes. Therefore, the implementation of Financial SIMDA in BAPPEDA of North Sulawesi Province has made financial management easier, so it needs to be monitored and improved. An internal control is needed to guarantee the quality of information from the output produced by Financial SIMDA. There are several elements of application internal control that must be applied, which includes: boundary controls, input controls, process controls, output controls.
\end{abstract}

Keywords: Internal control, Financial SIMDA, Financial data management

\section{PENDAHULUAN}

Teknologi informasi terus mengalami kemajuan seiring dengan berjalannya waktu. Perkembangan teknologi informasi mempengaruhi aktifitas yang dilakukan seseorang atau sekelompok orang dalam suatu organisasi menjadi lebih efektif dan efisien. Penggunaan teknologi informasi mempermudah proses pengelolaan data, administrasi dan manajemen dalam suatu organisasi. Dalam pemerintahan, teknologi informasi juga dimanfaatkan untuk membantu para Aparatur Sipil Negara (ASN) melaksanakan tugas dan tanggung jawab pekerjaannya dalam suatu instansi pemerintah. Pemerintah juga mempunyai kewajiban untuk menggunakan teknologi dalam proses pengelolaan keuangan. Kewajiban tersebut didasarkan pada Peraturan Pemerintah Nomor 58 Tahun 2005 tentang Pengelolaan Keuangan Daerah, yang menyebutkan bahwa kemajuan teknologi informasi wajib dimanfaatkan oleh pemerintah pusat maupun daerah untuk meningkatkan kemampuan dalam hal pengeloaan keuangan daerah dan juga dalam hal penyaluran informasi keuangan.

Untuk melaksanakan pengelolaan keuangan daerah yang baik, sumber daya manusia harus ditunjang dengan menerapkan teknologi informasi dalam sistem pengelolaan data keuangannya. Instansi pemerintahan membutuhkan suatu sistem informasi pengelolaan data keuangan berbasis teknologi yang dapat mengolah data dengan cepat, lengkap dan akurat, serta dapat memberikan informasi yang mudah dipahami, dapat dipercaya, dan terjamin kualitasnya, sehingga dapat digunakan dalam pengambilan keputusan. Salah satu bentuk teknologi informasi yang digunakan oleh pemerintah untuk membantu pengelolaan keuangan adalah SIMDA (Sistem Informasi Manajemen Daerah). SIMDA merupakan aplikasi yang dikembangkan oleh Satgas pengembangan SIMDA yang dibentuk BPKP untuk memudahkan pemerintah daerah dalam melaksanakan pengelolaan keuangan daerah yang efektif, efisien, 
transparan, akuntabel \& auditabel, dan juga sesuai dengan peraturan yang berlaku. Dalam SIMDA terdapat berbagai jenis program aplikasi, yang masing-masing memiliki fungsi yang berbeda, salah satu diantaranya adalah SIMDA Keuangan yang digunakan untuk membantu pemerintah daerah di bidang pengelolaan data keuangan. Badan Perencanaan dan Pembangunan Daerah (BAPPEDA) Provinsi Sulawesi Utara juga telah menerapkan SIMDA Keuangan dalam sistem pengelolaan data keuangannya. Penerapan SIMDA Keuangan pada BAPPEDA Provinsi Sulawesi Utara telah membuat proses pengelolaan data keuangan menjadi lebih mudah, sehingga perlu untuk diawasi dan ditingkatkan penerapannya. Oleh karena itu diperlukan suatu pengendalian intern untuk menjamin kualitas informasi dari output yang dihasilkan SIMDA Keuangan.

\section{TINJAUAN PUSTAKA}

Pengendalian Internal Aplikasi. Menurut Sanyoto Gondodiyoto (2007: 372), ruang lingkup pengendalian aplikasi dibagi ke dalam kategori sebagai berikut: pengendalian batasan (boundary controls), pengendalian masukan (input controls), pengendalian proses (process controls), pengendalian keluaran (output controls). Jadi, yang dimaksud dengan pengendalian aplikasi adalah sistem yang diterapkan dengan tujuan melaksanakan pengendalian internal, mulai dari pembatasan pengguna (user) sampai dengan pengawasan terhadap proses pemasukan, pengolahan, dan penggunaan data dari suatu sistem informasi berbasis teknologi informasi yang digunakan dalam kegiatan atau aplikasi tertentu.

Pengelolaan Keuangan Daerah. Berdasarkan pengertian pengelolaan keuangan daerah yang terdapat dalam Peraturan Pemerintah Nomor 58 Tahun 2005 dan dalam Peraturan Menteri Dalam Negeri Nomor 13 tahun 2006, pengelolaan keuangan daerah dapat diartikan sebagai proses yang dilakukan pemerintah daerah, mulai dari pembuatan anggaran (APBD), penggunaannya, sampai dengan pembuatan laporan (LKPD).

SIMDA Keuangan. Menurut Satgas pengembangan SIMDA, SIMDA Keuangan merupakan aplikasi yang digunakan untuk membantu pemerintah daerah pada proses penganggaran, penatausahaan, akuntansi dan pelaporan dalam melaksanakan pengelolaan keuangan daerah secara terintegrasi. Output yang dapat dihasilkan aplikasi ini berupa dokumen perencanaan anggaran, dokumen-dokumen administrasi untuk pembayaran, dan dokumen yang diperlukan untuk pembuatan laporan keuangan (LKPD). Jadi, dapat disimpulkan bahwa SIMDA Keuangan membantu pemerintah daerah mengelola data keuangan dalam keseluruhan kegiatan atau proses pengelolaan keuangan daerah dengan cara menghasilkan output berupa dokumen - dokumen dibidang keuangan.

\section{METODE DAN TEKNIK PENERAPAN IPTEKS}

\subsection{Metode Penerapan Ipteks}

Metode yang digunakan adalah pengendalian intern aplikasi menurut Gondodiyoto yang diterapkan terhadap SIMDA Keuangan yang digunakan dalam pengelolaan data keuangan.

\subsection{Teknik Penerapan Ipteks}

Teknik yang diterapkan yaitu dengan melalukan pengendalian intern aplikasi terhadap SIMDA Keuangan, yang meliputi: Pengendalian Batasan, Pengendalian Masukan, Pengendalian Proses, Pengendalian Keluaran.

\section{PEMBAHASAN}

\subsection{Gambaran Objek penerapan Ipteks}

Badan Perencanaan dan Pembangunan Daerah (BAPPEDA) Provinsi Sulawesi Utara merupakan instansi pemerintahan yang berada dibawah dan bertanggung jawab kepada Gubernur dan juga bertugas untuk membantu Gubernur menyusun dan melaksanakan 
kebijakan daerah dibidang perencanaan dan pembangunan daerah. BAPPEDA Prov. Sulut berada di kawasan perkantoran Pemprov Sulut yang berlokasi di jalan 17 Agustus No. 73, Kecamatan Wanea, Manado, Sulawesi Utara. BAPPEDA dipimpin oleh seorang Kepala Badan yang mendapat amanat dan menjalankan perintah langsung dari Gubernur. Terdapat pembagian strukur organisasi dalam BAPPEDA Prov. Sulut yang dikelompokan antara jabatan fungsional dan jabatan struktural. Jabatan fungsional yang ada, yaitu Sekretaris yang membawahi Sub Bagian Umum dan Kepegawaian, Sub Bagian Perencanaan dan Keuangan, Sub Bagian Umum. Sedangkan untuk jabatan struktural terdapat 4 bidang, yaitu Bidang Perekonomian dan Perdagangan (Ekonomi), Bidang Pemerintahan, Sosial dan Budaya (Sosbud), Bidang Infrastruktur dan Pengembangan Wilayah (IPW), Bidang Monitoring dan Evaluasi (Monev).

\subsection{Pembahasan}

BAPPEDA Provinsi Sulawesi Utara menerapkan SIMDA Keuangan untuk membantu pengelolaan data keuangan dalam melaksanakan proses penganggaran, penatausahaan, akuntansi, sampai dengan pelaporan. Untuk menjaga kualitas informasi dari output yang dihasilkan aplikasi ini, maka perlu untuk melaksanakan pengendelian intern terhadap SIMDA Keuangan tersebut. Terdapat beberapa unsur dalam pengendalian aplikasi diantaranya:

1. Pengendalian Batasan. Untuk menjaga agar data yang dimasukkan (input) ke dalam aplikasi sudah sesuai dengan aturan atau prosedur yang ditetapkan, diperlukan untuk membatasi siapa saja pengguna (user) yang dapat dipercaya untuk menggunakan aplikasi tersebut. Para pengguna (user) telah terlebih dahulu diberikan bimbingan dan pelatihan tentang cara atau prosedur yang benar untuk menggunakan aplikasi SIMDA Keuangan, kemudian masing - masing akan diberikan tugas dan tanggung jawab sesuai dengan kemampuan yang dimiliki dalam hal keterampilan menjalankan aplikasi SIMDA Keuangan tersebut. Misalnya dalam struktur organisasi BAPPEDA Prov. Sulut dalam sub bagian keuangan terdapat anggota yang diberikan tugas perbendaharaan, yang terdiri dari seorang bendahara dan beberapa pegawai lain untuk membantunya. Para anggota perbendaharaan akan mengikuti pelatihan dan bimbingan teknis (bimtek) sebelum dapat menggunakan aplikasi SIMDA Keuangan. Untuk menjaga kualitas ketika pemasukan data, yang dapat menggunakan atau mengoperasikan SIMDA Keuangan hanyalah para anggota perbendaharaan saja, sehingga pengelolaan data keuangan melalui aplikasi tersebut dapat dipercaya bahwa sudah dilaksanakan dengan cara yang benar, tepat dan akurat.

2. Pengendalian Masukan. Data yang akan diinput ke dalam aplikasi harus dipastikan sudah benar sesuai dengan aturan yang berlaku untuk mendeteksi sekaligus mencegah jika terdapat kesalahan ketika pemasukan data. Pengelolaan data keuangan menggunakan SIMDA Keuangan memiliki prosedur yang sudah ditetapkan, mulai dari pengguna (user) yang dapat menggunakannya sampai dengan data apa saja yang diperlukan oleh aplikasi dalam proses pembuatan suatu dokumen. Operator SIMDA Keuangan dalam BAPPEDA Prov. Sulut selalu melakukan pemeriksaan terlebih dahulu sebelum menginput suatu data, apabila terdapat kesalahan atau ketidaklengkapan data dalam dokumen yang diberikan, maka dokumen tersebut akan dikembalikan untuk dilakukan koreksi.

3. Pengendalian Proses. Untuk memastikan pengeloaan data dalam suatu aplikasi telah dilakukan secara benar. Pengendalian ini sebenarnya sudah dilaksanakan dalam pemrogaman aplikasi SIMDA Keuangan dengan adanya program untuk melakukan penolakan otomatis ketika data yang diinput tidak sesuai dengan yang diminta oleh aplikasi dan peringatan untuk mengoreksi bila ada kesalahan ketika penginputan, sehingga ketepatan data dapat terjaga selama proses pengolahan sampai dengan output dihasilkan. Pengendalian proses juga ditunjang oleh koordinasi yang dilakukan 
antar pengguna (user) aplikasi pada saat membuat dokumen menggunakan SIMDA Keuangan.

4. Pengendalian Keluaran. Output yang telah selesai diproses aplikasi harus dipastikan kembali apakah sudah akurat, lengkap dan didistrubusikan kepada para pengguna yang tepat. Output yang dihasilkan SIMDA Keuangan harus diperiksa kembali apakah sudah disajikan dengan benar dan sesuai aturan, sebelum didistrubusikan kepada pihak - pihak yang berhak. Misalnya ketika selesai membuat dokumen SPM (Surat Perintah Membayar), bendahara akan memeriksa apakah dokumen tersebut sudah benar dan kemudian ada tahap verifikasi yang akan dilakukan oleh pegawai yang bertugas melakukan verifikasi. Bila dokumen tersebut selesai diverifikasi dinyatakan sudah benar dan sesuai dengan aturan yang berlaku, maka dokumen dapat diserahkan kepada pihak - pihak yang berhak, sehingga SPM tersebut dapat dipergunakan untuk menerbitkan dokumen SP2D (Surat Perintah Pencairan Dana).

\section{KESIMPULAN DAN SARAN}

\subsection{Kesimpulan}

Pengelolaan keuangan pada Badan Perencanaan dan Pembangunan Daerah (BAPPEDA) Provinsi Sulawesi Utara menjadi lebih mudah dengan adanya aplikasi Sistem Informasi Manajemen Daerah (SIMDA) Keuangan yang telah membantu mengolah data dalam pembuatan dokumen-dokumen yang diperlukan pada proses Penganggaran, Penatausahaan, Akuntansi dan Pelaporan. Untuk menjaga kualitas informasi dari output yang dihasilkan SIMDA Keuangan, maka perlu untuk menerapkan pengendalian intern terhadap aplikasi tersebut, yang meliputi: pengendalian batasan, pengendalian masukan, pengendalian proses, pengendalian keluran.

\subsection{Saran}

Diperlukan pengetahuan dan pemahaman yang baik mengenai pengendalian intern aplikasi yang diterapkan dalam SIMDA Keuangan agar pengelolaan data keuangan dengan menggunakan aplikasi tersebut dapat dilaksanakan dengan efektif dan efisien, serta output yang dihasilkan dapat dipercaya untuk digunakan dalam pengambilan keputusan.

\section{DAFTAR PUSTAKA}

Gondodiyoto, Sanyoto. 2007. Audit Sistem Informasi + Pendekatan Cobit. Jakarta: Mitra Wacana Media.

Gaol, 2008. Sistem Informasi Manajemen: Pemahaman dan Aplikasi. PT Grasindo, Jakarta. Kumorotomo. 2004. Sistem Informasi Sektor Publik. BPFE UGM, Yogyakarta Harmadhani, Yuli. 2013. Analisis Penerapan Sistem Informasi Manajemen Keuangan Daerah (SIMDA keuangan) Dalam Dalam Pengolahan Data keuangan Pada Organisasi Pemerintah Daerah (Studi Kasus Pada Dinas Kesehatan Kabupaten Nganjuk). Jurnal Akuntansi Aktual. Vol. 2, Nomor 1, Hal. 25-33

Pilat, Juddy J., Jullie J. Sondakh, dan Hendrik Manossoh, 2016. Analisis Penerapan Sistem Informasi Manajemen Daerah (SIMDA) Keuangan Dalam Pengelolaan Keuangan Daerah pemerintah Kota Manado. Accountability. Vol. 5, Nomor 2, Hal. 72-83

Rahantoknam, Trivena A., Jantje J. Tinangon, dan Lidya M. Mawikere, 2017. Analisis Penerapan Sistem Informasi Manajemen Daerah (SIMDA) Keuangan Pada Badan Keuangan dan Aset Daerah Kabupaten Maluku Tenggara. Jurnal Riset Akuntansi Going Concern, Vol. 12, Nomor 2, Hal. 754-761 
Satgas Pengembangan SIMDA perwakilan BPKP. 2018. Pengenalan Sistem Informasi Manajemen Daerah (SIMDA), http://www.bpkp.go.id/sakd/konten/333/Versi2.1.bpkp, diakses tanggal 20 November 2018

Satgas Pengembangan SIMDA perwakilan BPKP. 2018. Sejarah SIMDA, http://www.bpkp.go.id/sakd/konten/334/Sejarah-SIMDA.bpkp, diakses tanggal 20 November 2018

http://library.binus.ac.id/eColls/eThesisdoc/Bab2HTML/2012200580AKBab2001/body.html, diakses tanggal 21 November 2018

Situs Resmi Bappeda Sulut, http://bappeda.sulutprov.go.id, diakses tanggal 21 November 2018

Republik Indonesia. 2005. Peraturan Pemerintah Nomor 58 Tahun 2005 tentang Pengelolaan Keuangan Daerah. Lembaran Negara RI Tahun 2005 No. 140. Sekretariat Negara. Jakarta

Republik Indonesia. 2006. Permendagri Nomor 13 Tahun 2006 tentang Pedoman Pengelolaan Keuangan Daerah. Jakarta: Departemen Dalam Negeri RI 